\title{
THE EXPRESSIVE POTENTIAL IN A DRAMATIC TEXT: BRECHT'S A RESPECTABLE WEDDING
}

\section{INTRODUCTION}

This article investigates how the linguistic shaping of a dramatic text influences its stage speech realisation. My initial assumption is that a dramatic text contains matrices of expressive potential 1 analogous to "matrices of performativity" (Ubersfeld 2002: 25). Just as a dramatic text "can be analysed by procedures that [...] bring to light kernels of theatricality" (ibid.), it is also possible to identify the linguistic features that reveal its expressive potential. By analysing the Slovenian translation of Bertolt Brecht's one-act play A Respectable Wedding ${ }^{2}$ and a part of its staging at the University of Ljubljana's Academy of Theatre, Radio, Film and Television (AGRFT) ${ }^{3}$ I aim to show how the linguistic structure of the written text gives rise to an actor's speech interpretation.

A dramatic text belongs to both the literary and dramatic arts; therefore "alongside reading, it also makes possible or even demands staging" (Kralj 1998: 5). Its literary-theatrical nature is usually implied visually: it is graphically divided into the main (dialogic) text, spoken during the performance, and the side text (stage directions or "didascalia"), containing the author's instructions for its dramatization (location, time, etc.). The expressive potential can also be graphically evident: first and most obviously as the vertical succession of utterances of individual characters that form the dialogic structure (vertical axis); second and more subtly as the linguistic components of speech interwoven into the semantic and syntactic structure of individual lines ${ }^{4}$ (horizontal axis).

In the dramatic theatre (theatre that has as its basis a dramatic text and considers speech "an important acting expression" (Humar et al. 2007: 54)), actors first convert the written language into speech during reading rehearsals, where, by using prosody in line with their understanding and experience of the content, they rely mostly on the written speech indications (punctuation, typesetting, stage directions). In the transfer

\footnotetext{
* kpodbevsek@gmail.com

1 I see expressive potential as a characteristic of the written text that uses linguistic features to indicate the speech realisation.

2 Malomeščanska svatba (henceforth Svatba), translation: Eduard Miler, Irena Novak Popov (Brecht 1993: 67-90). A Respectable Wedding (The Wedding), translation: Jean Benedetti (Brecht 1971: 258-282).

3 Performance of fourth-year students in the Old Power Station (2016). I was their "mentor" for speech.

4 An utterance/line is "a unit of dialogue spoken by one of the co-speakers before the next one begins to speak" (Humar et al. 2007: 164); cfr. also turn and turn-taking as used in conversation analysis (Verdonik 2007: 16).
} 
from the literary to the theatrical medium, a larger/smaller deviation always occurs from the written language (omitting/adding/reorganising), which is dependent upon the directorial concept and the theatrical context (scenography, costumes, etc.) and also upon the expressive potential in the written text. Certain playwrights devote detailed attention to the potential enunciation of the lines, remaining aware that they describe that "which will later be spoken and staged" (Vitez 2012: 354). This is why they choose the type of linguistic features that will organise the speech also in terms of rhythm. If the text's expressive potential is weak, it is possible to strengthen it in the staging. The actors, often on their own, consciously or unconsciously, reshape the linguistic structure of their lines when speaking (they change the word order, omit/add a word, etc.; see Podbevšek 2008: 51-60). The process is often overseen by a language consultant who, in line with the directorial vision, orients the entire staging to a common speech denominator and in doing so respects the speech specificity of the individual actors (psychophysical characteristics), the interpretive image of the characters and the stage context. The synergy among the mentioned factors creates a stage (speech) unity and a unique stage speech aesthetic.

\section{BRECHT AND A RESPECTABLE WEDDING}

One of the most important German playwrights, Bertolt Brecht (1898-1956), was a poet, writer, actor, director, theorist and reformer of theatre. He wrote many socially engaged plays ${ }^{5}$ with a clear critique of the capitalist system. Through his epic theatre he aimed to morally and socially educate the public with radically different performance strategies than bourgeois theatre. Using various features (cutting the action with songs, commentaries, projections), he broke the theatre illusion (through the so-called alienation effect) and forced the spectator into a critical experiencing of the stage action.

A Respectable Wedding belongs to Brecht's early works (1919). ${ }^{6}$ In it he reveals and ridicules the perverse world of the bourgeoisie. Nine typified characters (The Bride's Father, The Groom's Mother, The Bride, The Groom, etc.) at a wedding banquet show their spiritual emptiness and complacency through their words and actions. The gradual demolition of the furniture, crafted by the Groom himself, intensifies the tragicomedy of the situation and symbolises the end of the illusion of happiness and the collapse of interpersonal relations. The play ends with the guests leaving, the Groom and the Bride commenting about the events of the feast, and then departing to the bedroom, where the bed also collapses.

Although "we miss the complexity, the dramatic perfection and the deeper social analysis of his later works" (Šlibar 1985/86: 74), Brecht's play is interesting from a theatre studies viewpoint because it announces "the theatre of the grotesque and the

5 The Threepenny Opera (1929), Mr Puntila and his Man Matti (1940), Schweik in the Second World War (1944), etc.

6 From 1919-1921 Brecht wrote several one-act plays, among them, Die Kleinbürgerhochzeit, originally titled Die Hochzeit, first staged in Frankfurt (1926). The young Brecht was influenced by the Bavarian actor Karl Valentin, who in his improvised performances comically showed the bourgeoisie in confrontation "with the insidious environment" (Šlibar 1985/86: 75). 
absurd" (ibid.). We feel the exuberance of language typical of the absurdist drama (see 4.1), namely, in the semantic structure, where the puns create seemingly nonsensical connections with a comic effect. The manner of linguistic shaping is close to everyday speech communication. The expressive potential of the text is not only visible in the dialogue but also in the stage directions.

\section{THE EXPRESSIVE POTENTIAL IN STAGE DIRECTIONS}

Stage directions or "didascalia" are the playwright's instructions for the practical context in which the dialogue should be performed. They are intended for the reader to be able to follow "the inner relations and exchanges between individual speeches and other activities" (Inkret 1986: 93); they help to create the virtual space of the dialogue. Theatre makers respect them only partially, since the staging dictates its own speech context.

In Svatba there are 152 stage directions; they appear in different positions with different lengths and various functions. They indicate the performers' physical actions ( $\mathrm{g} a$ potolče po hrbtu / slapping him on the back, odmaši steklenico / opens bottle), the direction of the speech (prijatelju / to the friend, nevesti / to the bride), the way the sound is rendered (brutalno/brutally, grozeče/threatening), the end of a dialogue (tišina/silence).

In length, the first note stands out (11 sentences); it precisely describes the spatial context of the conversation and provides important details for the proxemics, ${ }^{7}$ since the speech "of a dramatic character [...] is always a speech in a space" (Inkret 1986: 94). The first note also reveals that the play starts in medias res:

Belo prepleskana soba z veliko pravokotno mizo v sredi. Nad njo rdeč lampijon. Devet preprostih, širokih lesenih stolov z nasloni za roke.[...] Večer je. Rdeči lampijon je prižgan. Za mizo sedijo svatje in jedo. (69) / A whitewashed room. with a large rectangular table in the middle. Above it a red Japanese lantern. Nine plain roomy armchairs. [...] It is evening. The Japanese lantern is lit. The wedding guests are seated around the table, eating. (259)

Stage directions appear within a dialogue before a line (a), between lines (b), after a line (c) and within a line (d):

\begin{tabular}{|l|l|l|}
\hline (a) & MATI prinaša na mizo To je polenovka. & $\begin{array}{l}\text { MOTHER bringing in a platter Here } \\
\text { comes the codfish. }\end{array}$ \\
\hline (b) & Odobravajoče mrmranje. & Mutterings of approval. \\
\hline & $\begin{array}{l}\text { OČE Tole me je spomnilo na neko } \\
\text { zgodbo. (69) }\end{array}$ & $\begin{array}{l}\text { FATHER That reminds me of a story. } \\
(259)\end{array}$ \\
\hline (c) & $\begin{array}{l}\text { PRIJATELJ Potem pa lahko gremo! } \\
\text { Gre ven. (86) }\end{array}$ & $\begin{array}{l}\text { FRIEND Then I guess we might as well } \\
\text { leave! Goes out. (278) }\end{array}$ \\
\hline (d) & $\begin{array}{l}\text { ŽENIN A tako. Se smeje. Zato tako } \\
\text { pridno sediš na svojem mestu? (86) }\end{array}$ & $\begin{array}{l}\text { GROOM Oh! Laughs. Is that why you've } \\
\text { been standing around so quietly? (278) }\end{array}$ \\
\hline
\end{tabular}

7 Proxemics investigates how the size and shape of the space, the spatial relations between the actors, their position on the stage, movement, etc., influence the speech. 
The expressive potential is shown by the instructions for the speaking of the lines (navihano/mischievously, zahlipa/sobs), for filling in the space between lines with unspoken sounds (Odobravajoče mrmranje / Mutterings of approval, Smeh/Laughter), for the absence of sound (Tišina/Silence, Premor/Pause). The number of 'sound' notes that suggest the choice of prosodic features is 58 .

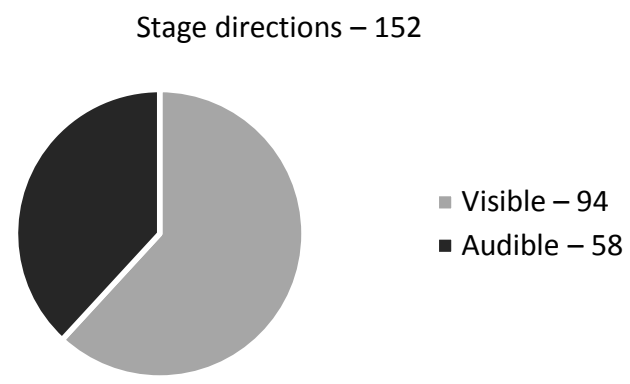

Figure 1: The relation between stage directions for audible and for visible action

For the rhythmic structuring of the dialogue in the vertical direction, the indications for the interruption of dialogue are especially visible. The so-called interturnus interruptions of speech (Katnić Bakaršić 2003: 177) are much more characteristic in the dense dialogue of a dramatic text than in everyday communication, and, likewise, their stage realisation is a strong theatrical mark. Brecht's text has 5 stage directions indicating silence, 6 indicating a pause. ${ }^{8} \mathrm{~A}$ silence (also a pause) ${ }^{9}$ concludes a speech event, delineating it from the next one and indicating the atmosphere between speeches: embarrassment, awe, tension, etc. In the written text the dialogic chain structures the conversation in the vertical direction, while onstage it structures an actor's speech time.

Silence indicates an embarrassing moment, e.g., after the Young Man's solemn speech to the young newly-weds when he attempts to get all the guests to sing: Začne peti, ker mu nihče ne pritegne, kmalu sede. Tišina (73) / He starts singing, but stops short and sits down when no one joins him. Silence (264).

The Father's long-winded story about Uncle August, who on his deathbed vulgarly refused to see a priest - Rekel je: Poližite mi ..., no, saj veste kaj (75) / He said: Kiss my . . . well, you know what (266) - is also followed by silence. The guests do not respond to the concealed vulgarism; they show their negative reaction towards Father's intrusive storytelling through silence or rather by abstaining from commenting. Silence lends the scene a grotesque note, since Father's stories speak about the everyday world in which they live, yet, they want him "in that sublime moment to give up, to forget it, to delude it" (Poniž 1985/86: 72).

8 I see silence as a longer, pause as a shorter absence of speech. In the German original Stille and Pause are used distinctively (Brecht 1967: 2720, 2739). See Poniž (2006: 27-44) and Katnić Bakaršić (2003: 175).

9 It is in realist literature that playwrights such as Chekhov, Ibsen and Strindberg begin to intentionally dedicate a role to silence. In the theatre of the absurd silence became a key part of the dramaturgy (Beckett, Ionesco, Pinter) and "a measure of dramatic rhythm" (Gantar 2006: 243). 
Stage directions for pauses appear also after the mild conflict between the Friend and the Groom about whether the Friend is too tired after dancing. The Young Man interrupts the impasse with an unexpected question: Ste tudi vi videli gledališko igro Baal? (82) / Did you see that play Baal? (274)..$^{10}$ Three lines of commentary about Baal follow, then silence, which stresses the negative opinion about the play (silna svinjarija / unadulterated filth). Father and the Friend each break the embarrassment with their own line about family life, but the conversation does not pick up; again there is a pause. The Groom tries to lighten the mood - Tako. Poveselimo se malo! Saj se ne ženim vsak dan (83) / All right, let's have merriment! I don't get married everyday (274) - but he is not successful; again a pause. Only the Friend's idea of playing cards returns the conversation to a regular rhythm.

Stage directions that describe the manner of speech are short, adverbial (e.g., polglasno / in a half-whisper, navihano/mischievously) and found 21 times. There are 26 notes for unspoken sound events, most of them short: smeh/Laughter, vsi trkajo s kozarci / All clink glasses; some are also longer: $V$ tem trenutku začnejo zvoniti cerkveni zvonovi (73) I At this moment church hells begin to ring (264). Some are 'sounded-unsounded' notes, like the last - when the Groom drags the Bride off to bed: Jo odvleče ven. Tema. Slišimo, kako se podira postelja (90) / Drags her out. Darkness. Sound of bed collapsing (282).

Sound-related stage directions -58

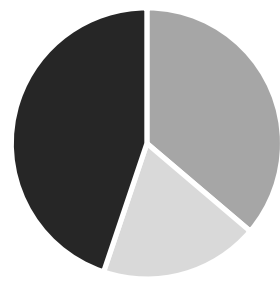

- Speaking the utterance -21

Silence, pause -11

- Other sounds -26

Figure 2: The relation between the notes for the speaking of lines, silence/pause and other sound events

\section{THE EXPRESSIVE POTENTIAL IN THE DIALOGUE}

\subsection{Gossip as a Stylistic Procedure}

The action in the one-act play is reminiscent of a coarse Chaplinesque farce or "the slapstick comedies of silent film" (Šlibar 1985/86: 75): breaking chairs and tables, the response of the wedding guests to vulgar jokes and sexual innuendos. The unrefined comedy of the external action is complemented by the dialogue's witty puns, selfreferencing (the guests discuss Brecht's play Baal), unexpected turns (Imate radi romantiko? - Ja. Zelo. Zlasti Heineja. Tako srčkan profil ima!(70) / Are you romantically inclined? - Oh, yes. I'm crazy about Heine. He has such an adorable profile! (260)), vulgarisms (žlampajo/eating hastily, pokavsal/banged), absurdisms (Ljubi gospod bog je nekoč hotel inkognito na sprehod. Ker pa si je pozabil privezati kravato, so ga

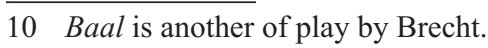


prepoznali in ga odpeljali v norišnico (81) / One day the good Lord decided to go for a stroll incognito. But he forgot to put on a tie, so they recognized him and threw him in the loony bin (272)). Meaningless phrasemaking is shown in the Young Man's address to the young newly-weds, full of worn out, seemingly poetic phrases (deviška nevesta, $v$ viharjih življenja dozoreli ženin (73) / an innocent maiden, a man who has weathered life's stormy seas (264)) taken from Govori na svatbah / Speeches for Wedding Receptions, which the Husband reveals rather tactlessly. The characters play out speech and behaviour patterns, they talk but have nothing to say, forced as they are to maintain the pointless conversation in order to preserve their bourgeois appearance and conceal their spiritual emptiness. The action intensifies grotesquely and the truth is finally bared in the closing dialogue: the Groom and the Bride - when left alone - "replay all that happened [...] in words" (Poniž 1985/86: 73) and comment on their failure with Saj je vseeno / It doesn't matter and Nič hudega (90) / Who cares (282).

\subsection{Interruptions}

Interruptions are a prominent linguistic tactic. The exchange of lines takes three forms: the current speaker gives another person the chance to speak; the second speaker decides himself that he will speak; nobody decides to speak (omission of a line) - collectively creating an "interturnus break" (Katnić Bakaršić 2003: 55).

In Svatba, the second form of interruption is most frequent: different characters intentionally interrupt the Father's repetitive attempts to tell a story associated with the events at the wedding feast. When the Mother brings the codfish to the table, it reminds the Father of an uncle who choked on a fishbone. As everyone knows the Father's passion for storytelling, the Bride already interrupts him after his short announcement. But he persists. He starts to tell the story, then the Mother interrupts by telling her son to take the tail. But the Father is not thwarted and tells the story even more elaborately. The Mother interrupts the Father again by asking the guests how they like the food; he tries to fight for his speech space, but the Mother interrupts again. The action continues in this way until the Father nevertheless finishes telling his tale.

\begin{tabular}{|l|l|}
\hline OČE Krili in postaja zmerom bolj & FATHER Flapping and turning as blue as \\
modrikast, kot kakšen krap, pri tem & a carp and knocks over a wineglass and \\
prevrne vinski kozarec in nas neznansko & $\begin{array}{l}\text { scares everybody out of their wits. We } \\
\text { prestraši, lopnemo ga po hrbtu, tolčemo, } \\
\text { thumped him on the back, gave him a good }\end{array}$ \\
kamor prileti, in on, on ti bruhne čez celo & going over, and he, he threw up all over the \\
mizo. Hrane se ni pritaknil nihče več - mi & table. We couldn't go on with our dinner \\
smo se pa zabavali, zunaj smo vse sami & - we were delighted, we ate it outside later \\
pojedli, navsezadnje sem bil jaz birmanec & on all by ourselves, after all it was my \\
- torej, čez celo mizo, in ko smo ga srečno & confirmation - anyhow, all over the table, \\
spet spravili k sebi, je rekel z globokim, & and when we had him afloat again he said \\
zadovoljnim glasom, imel je krasen bas & in his deep cheery voice - he had a fine \\
in je pel v zboru, tudi o tem vem imenitno & bass and sang in the choral society, that's \\
zgodbo, torej, rekel je - & another great story, anyhow, he said - \\
\hline
\end{tabular}




\begin{tabular}{|l|l|}
\hline $\begin{array}{l}\text { MATI No, kako vam tekne riba? Zakaj } \\
\text { nihče nič ne pripomni? }\end{array}$ & $\begin{array}{l}\text { MOTHER Well, how's the fish? Why } \\
\text { doesn't anybody say anything? }\end{array}$ \\
\hline OČE Izvrstno! Torej, rekel je & FATHER Delicious! So he said - \\
\hline MATI Ampak, saj še poskusil nisi! & MOTHER You haven't even tasted it! \\
\hline OČE Ja, že jem, že jem. Torej, rekel je & $\begin{array}{l}\text { FATHER All right, now I'm going to eat. } \\
\text { So he said - }\end{array}$ \\
\hline MATI Jakob, vzemi si še en kos! & MOTHER Have some more, Jacob! \\
\hline ŽENIN Mama, oče vendar pripoveduje! & GROOM Mother, Father's telling a story! \\
\hline $\begin{array}{l}\text { OČE Hvala. Torej, polenovka, a ja, rekel } \\
\text { je: otroci, zdajle se mi je pa skoraj zaletelo. } \\
\text { Ampak hrana je bila neužitna. } \\
\text { Smeh. (69) }\end{array}$ & $\begin{array}{l}\text { FATHER Thank you. Anyway, the codfish, } \\
\text { oh yes, he said: Children, I almost choked } \\
\text { to death. The food was ruined. } \\
\text { Laughter. (259-260) }\end{array}$ \\
\hline
\end{tabular}

Already in the first story, interrupting the Father becomes a visible linguistic and dramaturgical tactic that significantly contributes to the formation of his character and as a repetitive dialogic pattern gives the entire text a specific rhythm.

\subsubsection{Song as Interruption}

The insert "Balada o deviškosti v duru"11 (sung by the Friend) represents a special type of interruption of the conversation. ${ }^{12}$ The ballad consists of 5 rhyming 7-line stanzas. The penultimate stanza has 9 lines, 2 of which - in parentheses - vulgarly describe a hasty sex act, the brackets signalling the fleeting insignificance of the deed.

The poem tells the story of a groom who does not dare desecrate his bride's virginity before the wedding. He therefore finds other means of satisfying his craving. The Bride also finds herself a guy: dedca in pol / No shy, shrinking violet, he, who wastes no time in "doing" her: se je z njo poravsal, / kar na štengah jo pokavsal! / Spread her on the stairs and banged her / Laughing at propriety. Both are thus satisfied that their "chastity" has been preserved until the wedding. Laughter follows the song (Žena se smeje ( Wife giggles), the Groom wants to move the conversation in a different direction as soon as possible, since the song hints at the question of the Bride's own chastity.

\subsection{The Length of Utterances}

The utterances in Svatba are mostly short (1 line, often partial) or medium (2 lines, usually partial), thus, long utterances (over 3 lines) are even more noticeable. Father's utterances are especially long; the longest is 21 lines (74/265), the Husband's affective description of life with his wife is 15 lines (86/277) and the Young Man's solemn speech is 12 lines (73/264). Long utterances express the desire to dominate, egocentrism or a speaker's individual style. The effects can be varied: "they can elicit boredom or unfriendliness," sometimes they can also be acceptable (Katnić Bakaršić 2003: 56).

11 "Ballad of Chastity in Major" (Brecht 1971: 270-271), Slovenian translation: Tone Pretnar (Brecht 1993: 79).

12 The inserted poem announces a staging strategy used in Brecht's later texts: breaking the stage action with a socially critical song. 
In Brecht's play, the listeners generally respond to the Father's longer utterances by interrupting him or changing the topic or doing both. Short utterances prevail, which signals a faster conversational rhythm.

Entire text - 527 utterances

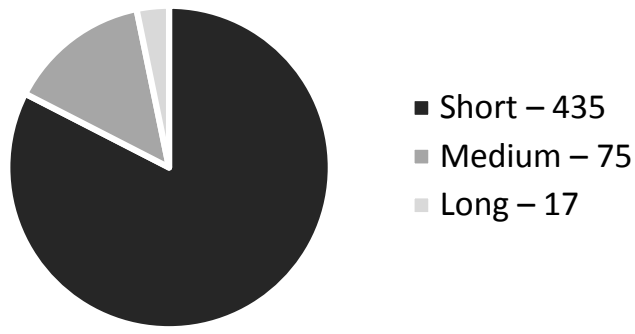

Figure 3: The relationship between utterances of different lengths

\subsection{Graphic Marks for Speech Realisation}

Punctuation is an important graphic mark for speech realisation. In Svatba, ellipses demonstrate the process of shaping a thought or withholding speech: Oprostite, mislil sem ... (72) / I'm sorry, I thought ... (263), Bojim se, da stol ... (81) / I'm afraid that chair ... (273). The underlined words in the Slovenian translation are surprising: Jakob, vzemi š en kos (69) / Take that piece, Jacob (262), Zelo dobro (70) / That's a good one! (260); in the original the same words appear with expanded spacing: Jakob, nimm n o c h ein Stück, S e h r gut (Brecht 1967: 2716). Both variations suggest emphasis. The noticeable number of exclamation marks shows the emotionality of the lines: In moja sestra na hodniku! Za crknit! - In kako so zijali, ko se omara ni hotela odpreti! (90) / And my sister out in the hall! Enough to make you die langhing! - And the way they gaped when the cupboard door didn't open! (282). Finally, dashes help shape the rhythm of longer statements (see 4.2).

\subsection{Linguistic Elements of Spontaneous Speech}

Brecht's linguistic shaping of the dialogues strives, both vertically and horizontally, to create a feeling of spontaneity. Spontaneous speech is a type of spoken language ${ }^{13}$ actualised as "an acoustic interactive event, [...] largely unprepared in advance, happening in real time and impossible to separate from the circumstances in which it takes place or arises" (Zemljarič Miklavčič 2008: 93).

The actor's speech is based on a written text and is not spontaneous; at least the actor speaks a text prepared in advance and responds to reactions of co-actors prepared in advance as well as to an external linguistic context prepared in advance. Because he is aware of the characteristics of spontaneous speech "he can also imitate all of its features in a [...] non-spontaneous text" (Verdonik 2007: 11).

13 Spoken language can also be realised as reading aloud or as a memorised text. 
Creating a feeling of spoken spontaneity is an important characteristic of the contemporary stage speech aesthetic. ${ }^{14}$ The written linguistic marks in the dramatic text help actors achieve spontaneity, especially with effective, text and stage appropriate prosody. Generally, as Verdonik observes (2007: 11), there are not many linguistic indicators for spontaneity in written texts, but because a dramatic text has inherent expressive potential, these kinds of marks are not so rare and do not go unobserved.

\subsubsection{Deixis and Discourse Markers}

In Svatba, the conversation is anchored in a situation that the speakers share (a wedding banquet); therefore frequent deictic terms create textual coherence through their reference to people, spaces, time and context. In texts we find "personal (I, you), temporal (now) and spatial (here)" deixis (Katnić Bakaršić 2003: 15). Deixis is connected to the dialogic nature of the drama and to its dominant time of the action, which is the present. ${ }^{15}$ Tole me je spomnilo na neko zgodbo (69) / That reminds me of a story (259) - tole/that refers to the codfish that Mother has brought to the table. The involvement of the guests in the same situation and the rather common knowledge allows for relatively large deictic referencing: Tale svetilka pravzaprav še ni dokončana (70) / I suppose that lamp never got finished? (260), Kako tukaj prijetno diši (70) / It smells so good here! (261).

Discourse markers allow a larger expressive potential: torej/so, anyway, no/well, seveda / of course. These expressions show the speaker's attitude to the subject, to the co-speaker, his emotional engagement, "the connection of the discourse to the context" (Zemljarič Miklavčič 2008: 96). They often signal the beginning, the continuation or the end of an utterance; with them, a speaker can hold the listener's attention: No, kako vam tekne riba? / Well, how's the fish?, Torej, polenovka, a ja, rekel je (69) / Anyway, the codfish, oh yes, he said (260). In Father's story about the uncle who choked on a bone, tore $^{16}$ as a continuity marker is used seven times and it also has a rhythm-producing role.

\subsubsection{Corrections, Repetitions, False Starts}

Noticeable linguistic marks of spontaneity in Brecht's text include corrections ${ }^{17}$ or rather 'errors' in the syntactic structure - incomplete thoughts, repeats, changes to syntax. By correcting, the speaker "reveals the processes that take place in the production of speech" (Verdonik 2007: 121) or "simultaneously, while speaking, plans how he will continue the statement" (ibid.: 123). An ellipsis often indicates the processing of a thought: Jajca, hehehe, jajca, to je, hehehe, zelo dobro ... jajca, to je izvrstno; sicer, hehehe, sicer ni nič, hehehe, to je izvrstno ..., hehehe (72) / Eggs, hahaha, eggs,

14 In the early $20^{\text {th }}$ century, actors' speech moved away from spontaneity as a means of differentiation from everyday speech. Actors "by using facial expressions and gestures [...] exaggeratedly exposed some prosodic features [...] and with that gave speech an unnatural sound image" (Podbevšek 2010: 233).

15 The epic speaks "of events separated from now and here" (Katnić Bakaršić 2003: 17).

16 In English anyway is used twice, anyhow twice and so twice in this same speech.

17 Dysfluencies is also used, see Clark 2002. 
that's hahaha, rich ... eggs are rich, marvelous; otherwise, hahaha, otherwise it's no good, hahaha, that's really marvel lous ... hahaha (262). Repetitions here are a sign of reticence - the character does not want to state his lewd thoughts; dysfluency offers an effective speech realisation. Repetitions, false starts, incorrect continuation are characteristic especially for the Father, who is fighting for his speech time (see 4.2.).

\section{AN ACTOR'S SPEECH REALISATION}

In their interpretation of their lines, the actor gives meaning to the written material mainly with the appropriate use of prosodic features (pauses, stress, tempo, etc.). Through these techniques he creates a feeling of speech spontaneity that can be intensified with the changing of lexis and syntax. I will cite a short section of Father's line.

Written text:

OČE [...] in rekel nekaj, česar tukaj ne morem ponoviti. Bilo je nekaj grobega, takšnega, kakršen je stric pač bil. Res ne morem ..., ampak zaradi zgodbe ... Vseeno moram povedati, sicer ne bo razumljiva. Rekel je: Poližite mi ..., no, saj veste kaj. Ko je to izdavil, je, si lahko mislite, umrl. Postelja je ostala, spravil jo bom na podstrešje za vaju, kar pridita ponjo. (Pije). (75)

FATHER $[\ldots]$ and says something which I can't repeat here. It was a bit salty, but then Uncle was a saltyman. No, I really can't. But the story ... I guess I'll have to say it or the story won't make sense. He said: Kiss my ... well, you know what. After he said that, and as you can imagine it took quite an effort to say it, he died. We still have the bed up in the attic. Come to think of it, I'll get it ready for you. You can pick it up if you ever want it. (Drinks). (266)

Speech realisation (transcript from recording ${ }^{18}$ linguistic changes in bold):

OČE [...] in rekel nekaj, nekaj grobega, no, nekaj, nekaj neizrekljivega, takšnega, kakršen je stric pač bil, no. Ampak ne morem ... zaradi zgodbe, veš, zaradi zgodbe moram povedat. Sicer zgodba ne bo razumljiva. Torej - stric Avgust je rekel: Poližite - mi (nekdo od svatov reče zelo potiho: ga) - Ga. Poližite mi ga. In ko, ko je to izdavil, je, si lahko mislite, kar lepo crknil. Ampak, draga moja, postelja je ostala, spravil sem jo za vaju, kar pridita ponjo. Na zdravje.

FATHER $[\ldots]$ and he said something so salty, well, something so unspeakable, but then that's just how Uncle was, well. But, I can't ... because of the story, you know, because of the story, I guess I'll have to say it. Otherwise, the story just won't make sense. So - Uncle August said: Suck - my (one of the guests says it very quietly: dick) - Richard. Suck my Richard. And then, after he said that, he, can you imagine, just up and croaked. But, my dear, we still have the bed, I saved it for you, just come and get it. Cheers. ${ }^{19}$

18 Video library, AGRFT.

19 English rendering by the translator of this article. 
In the spoken realisation the actor repeats, adds, omits, or exchanges words, changes formulations, and in doing so enhances speech spontaneity, which is also co-shaped by prosody, especially pauses with their production of rhythm. The speaker breaks the sentence Poližite mi / Suck my ... into two parts with a long pause, an even longer dramatic pause follows $m i / m y$, in which the speaker's facial expression impels the wedding guests to complete the thought (ga/dick), then he himself says ga/Richard very loudly and says the entire sentence (Poližite mi ga/ Suck my Richard), bringing the story to its speech-dramaturgical peak. The apparent linguistic redundancy - the meaning is conveyed by means of intensive prosody in combination with (numerous and long) pauses and, in some parts, loudness and tempo (agogics) - creates a feeling of a spontaneous speech event, blending in with the external action.

\section{CONCLUSION}

Using the example of Brecht's play the article has illustrated the presence of a matrix of expressive potential in a dramatic text, shown in the stage directions and the dialogues, which reveal elements of spontaneous speech (interruptions, deixis, etc.). Recognising signs of spoken discourse in a written text is imperative for its performer. In comparing the written text with the stage speech realisation we see that the text's expressive potential helps to stimulate the actor's creativity in adapting the prosodics and the lexicalsyntactical structure to the stage context.

\section{References}

BRECHT, Bertolt (1967) “Die Kleinbürgerhochzeit.” In: E. Hauptmann (ed.), Gesammelte Werke 7. Frankfurt am Main: Suhrkamp Verlag, 2713-2744.

BRECHT, Bertolt (1971) "The Respectable Wedding." In: J. Willet/R. Manheim (eds), Bertolt Brecht, Collected Plays Volume 1. New York: Vintage Books, 258-282.

BRECHT, Bertolt (1993) “Malomeščanska svatba.” In: M. Kranjc (ed.), Šest iger. Ljubljana: MK, 67-91.

CLARK, Herbert H. (2002) "Speaking in time." Speech Communication 36, 5-13.

GANTAR, Jure (2013) "Vse ob pravem času." In: K. Podbevšek/N. Žavbi Milojević (eds), Govor med znanostjo in umetnostjo. Maribor: Aristej, AGRFT, 237-247.

HUMAR, Marjeta et al. (eds) (2007) Gledališki terminološki slovar. Ljubljana: Založba ZRC, ZRC SAZU.

INKRET, Andrej (1986) Drama in gledališče. Ljubljana: DZS.

KATNIĆ BAKARŠIĆ, Marina (2003) Stilistika dramskog diskursa. Zenica: Vrijeme.

KATNIĆ BAKARŠIĆ, Marina/Vesna POŽGAJ HADŽI (2012) "Didaskalije u suvremenoj slovenskoj drami." In: Mateja Pezdirc Bartol (ed.), Slovenska dramatika/ Slovene Drama. Ljubljana: Znanstvena založba Filozofske fakultete, 127-137.

KRALJ, Lado (1998) Teorija drame. Ljubljana: DZS. 
PODBEVŠEK, Katarina (2008) "Govor kot gledališko izrazilo (na primeru Flisarjevega Akvarija)." In: M. Pezdirc Bartol (ed.), Slovenski jezik, literatura, kultura in mediji. Ljubljana: Center za slovenščino kot drugi/tuji jezik pri Oddelku za slovenistiko Filozofske fakultete, 51-60.

PODBEVŠEK, Katarina (2010) "Spreminjanje odrske govorne estetike v slovenskem gledališču 20. stoletja." In: B. Sušec Michieli/B. Lukan/M. Šorli (eds), Dinamika sprememb v slovenskem gledališču 20. stoletja. Ljubljana: AGRFT, Maska, 195-239.

PONIŽ, Denis (1985/86) "Brecht in brechtovski teater med malomeščani in revolucijo." Gledališki list Drame SNG Ljubljana, uprizoritev 4, 70-74.

PONIŽ, Denis (2006) "Med glasovi in tišino, med besedami in molkom (Vloga tišine in molka v dramskem besedilu)." In: K. Podbevšek/T. Gubenšek (eds), Kolokvij o umetniškem govoru 2. Ljubljana: AGRFT, 27-44.

ŠLIBAR, Neva (1985/86) "Mladi Brecht in njegova Svatba." Gledališki list Drame SNG Ljubljana, uprizoritev 4, 74-76.

UBERSFELD, Anne (2002) Brati gledališče. Ljubljana: Mestno gledališče ljubljansko. VERDONIK, Darinka (2007) Jezikovni elementi spontanosti v pogovoru: diskurzni označevalci in popravljanja. Maribor: Slavistično društvo.

VITEZ, Primož (2012) "Gledališki govor kot jezikovna iluzija.” In: M. Pezdirc Bartol (ed.), Slovenska dramatika/Slovene Drama. Ljubljana: Znanstvena založba Filozofske fakultete, 353-359.

ZEMLJARIČ MIKLAVČIČ, Jana (2008) "Iskanje odgovorov na Vprašanja govorjenega jezika." Jezik in slovstvo LIII/1, 89-107.

Translated into English by Jana Renée Wilcoxen.

\section{Abstract \\ THE EXPRESSIVE POTENTIAL IN THE LINGUISTIC STRUCTURE OF A DRA- MATIC TEXT: BRECHT'S A RESPECTABLE WEDDING}

The article discusses the linguistic shaping of a dramatic text and its influence on the text's stage speech realisation, using the Slovenian translation of Brecht's one-act play A Respectable Wedding as an example. A dramatic text typically has a specific and also graphically visible - textual and linguistic structure that indicates its speech intention. A linguistic analysis of Brecht's text reveals a great expressive potential, both in the stage directions (especially the stage directions for pauses, silence, spoken realization) and in the dialogue (characteristic linguistic elements of spontaneous speech). A short comparison of the text with the stage speech performance shows that the actor used not only prosody (especially pauses) to semantically enrich and rhythmically organise the written language, but also linguistic interventions into the lexical and 
syntactic structure (repetition, addition, omission, etc.). The great expressive potential of the text thus stimulated the actor's speech and interpretive creativity.

Keywords: actor's speech, dialogue, stage directions, elements of spontaneous speech, expressive potential of a dramatic text

\section{Povzetek \\ GOVORNI POTENCIAL V DRAMSKEM BESEDILU:

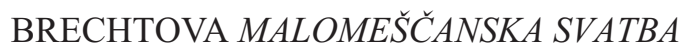

Članek obravnava vpliv jezikovne oblikovanosti dramskega teksta na njegovo odrskogovorno realizacijo, in sicer na primeru Brechtove enodejanke Malomeščanska svatba. Običajno ima dramsko besedilo specifično, tudi grafično razvidno, besedilnojezikovno strukturo, ki kaže govorno intenco. Jezikovna analiza Brechtovega teksta je razkrila velik govorni potencial, tako v didaskalijah (oznake za premore, tišino, govorno izvedbo) kot v dialogu (za spontani govor značilne jezikovne prvine). Kratka primerjava teksta in odrske govorne izvedbe je pokazala, da igralec pisnega jezika ni semantično obogatil in ritmično strukturiral le s prozodijo (zlasti s premori), pač pa tudi z jezikovnimi posegi v leksično-sintaktično strukturo (ponavljanje, dodajanje, izpuščanje itd.). Velik govorni potencial teksta je spodbudil igralčevo govornointerpretativno ustvarjalnost.

Ključne besede: dialog, didaskalije, govorni potencial dramskega besedila, igralski govor, prvine spontanega govora 